\title{
RITUALS FOR HARMONY: EXPLORING THE BERSIH DUSUN LOCAL GENIUS BEHIND RUBBER TAPPING
}

\author{
Hasse J. \\ Muhammadiyah University of Yogyakarta
}

\begin{abstract}
Differences have long been a natural marker of the dynamics of the relationship of society. Differences often become obstacles in creating social stability. Diversity can be a strength if managed properly, but may become a source of conflict in case of faulty management. This short article addresses the issue of how to manage diversity so as to produce harmony in society that has different beliefs. There are three basic things defined in this paper. First, a society is capable of being integrated through commonly shared events. Second, providing room for all of the elements of society gives rise to collective solidarity which allows differences --even conflicts-- to be turned into unity. Third, the typicality of ritual that continues to be practiced in society can be optimized to serve as the medium that manages the differences and turned them to peace.
\end{abstract}

Keywords: Management of Diversity, Relations, Local Genius

\section{INTRODUCTION}

In the teaching of any religion, there is a doctrine which asserts the truth of each religion. It is then shifted into claims of religious truth that aims to show the faith and constancy of the religion one believes in. However, conflict often emerged from such a claim because it tends to take sides. The difference of perspectives in understanding religious truth makes followers of religions exclusive because there is always presumption that their religion is the most correct, while others are wrong. It is closely related to the religious teachings (especially Islam) that no existing religion (will be accepted) by Allah except Islam and thus Muslims strongly hold on to this belief and practice. People of other faiths also have similar belief so they have comparable tendency, namely claiming their religion to be the best and most correct.

Religion is in fact the perfection of human existence, the source of vitality that embodies the changes of the world and preserves them. Religion is also one of the sources of value, role, significance, and even the highest contribution in 
the life of human beings. Religion, if seen in the context of the function, is capable of being the power of integration for its adherents. Apart from that, religion sometimes also plays the role of disintegration, becoming one of the factors in the occurrence of conflict among humanity, although this is still a debatable case. In the name of religion, people can come together and become strong, build a civilization and advance together. Nevertheless, also in the name of religion, people can kill each other and destroy the existence as well as the roles and functions of each other.

Diversity should be seen as the uncontested reality that becomes one of the important conditions that must be addressed openly and thoroughly. Diversity which definitely contains differences should not be considered a factor that triggers a conflict. Differences of identity (religion), often triggers the occurrence of disharmony among a diverse society, even war such as the crusade involving Islam and Christianity. Socioreligious conflict can be minimized when religious followers are willing to appreciate and respect the existence of others who are different. As a matter of fact, not only do religious followers need to appreciate each other but at the same time they also have to acknowledge other groups who have their own creed. Recognizing the existence of other religions is not in order to state that all religions are the same, but to acknowledge in terms of difference as something that we definitely have to live with.

Cooperation among religious followers can be reached if it is done without any prejudice, suspicion and when each does not stand on his own religion, ethnic group, or other self-interest. The presence of religious groups with each attributes could in fact open the opportunity for the occurrence of conflict with each other. Religion which is believed to be a factor of integration, on certain conditions, tends to create conflict involving many parties. However, in one of the rural areas in Yogyakarta, two religious groups, while continuing to compete with each other, can still get along well side by side. One of the questions closely related to this condition is how do they manage their differences? To be more specific in this case, how is the process of unity running amid diversity that accompanies the two faiths?

\section{CONCEPTUAL FRAMEWORK}

There are two important concepts used in this paper, namely dialog and ritual. The concept of dialog and the ritual used to view any relation established between Muslims and Buddhists who are united by a routine rituals they hold together in a hamlet inspired the writing of this paper. 
Concept of dialog. This concept is used in order to see what kind of communication hasbeen establishedamong theresidents of Pedukuhan Sonyo to date. Dialog is often understood solely as conversations between people. The focus is only on the method, rather than on a more substantive level or what lies behind that dialog. In the tradition of a society, the dialog takes place not only in daily socilization, but also in various forms of activities. Up to now, we can still find a variety of routine activities of the residents of the hamlet in which there is a lot of dialog among them such as in festivals, rituals, and implementation of various activities that involve a lot of other people.

In the context of religion, dialog is not meant to unify the perception of differences because every religion has a point of difference that must be emphasized to differentiate it from other religions. Dialog in the context of religion is in the form of interreligious dialog. The dialog is underway to build peaceful hearts and minds between various religious groups. It is the communication between two or more persons in a religious level. The dialog is the way that leads to the truth. The dialog is also a form of cooperation in projects of common interest which are not afflicted with hidden political objectives.

One thing to note related to inter-religious dialog is the nature of the dialog itself. Dialog is not a debate in which each side insists on who is right and superior. The dialog is nevertheless a way of affirming one's own faith in the religion itself and also a way of enriching their knowledge and understanding of the truth found in religions other than his own. Such dialog will affirm the belief of the religion and give space to other followers of faiths to practice their own belief. Information about other religions is very important in order to build better perception regarding the existence of other religions. The dialog also should never be an attempt to unify different religions, but it should be a form of cooperation between adherents of different religions. Dialog is not a charity, mission, or an activity aimed at inviting other religious group to embrace a certain religion.

Related to inter-religious dialog, four different typologies are offered. First, the replacement model. This dialog model is born from the spirit of there is only one true religion. This spirit triggers exclusive views among the adherents of a certain religion because of the claim that only one's own religion is the most correct. No the truth is out there except in the religion one embraces the truth can be found. Salvation only exists and can be found in one's own religion.

Second, the fulfillment model. This dialog models originates from the view that the one fulfills the many. This dialog model is actually almost identical to the first model; the only difference is that it still provides room 
for the presence of truth for other religions. Truth in one's own religion becomes the source of truth for others is a simple view of the model of this dialog. There is salvation in one's own religion that spreads to the others so that the salvation of other religions is found.

Third, mutuality model. This dialog model is more open to the truth of other religions. Out there there is a lot of truth so that it requires a dialog to find it. This model assumes that many true religions called to dialog. On a more philosophical and mystical level, the truth can be found everywhere. Truth is not focused on one religion, but it can be found through dialog. So is salvation. There are many paths that can be taken to reach it. This model of dialog does not impose the will to say that one's own religion is the most correct.

Fourth, acceptance model. This dialog is almost the same model as the third model above. The difference is in the assumption that there are many true religions; so be it. This dialog model is considered the most open. The dialoggoes from the assumption that there is a lot of truth. To achieve salvation is not only through one particular religion, all religions allow it. Dialog will be much better if based on an assumption like this model because there is no will to impose on other religions to change. All religions (followers) remain at their respective beliefs, without propagating religious truth which may bring harms to other religions.

Rituals. The second concept used in looking at the Buddhist-Islamic Relations in Pedukunan Sonyo is the ritual. This concept is used to understand more about the ritual performed by the village residents twice in three years' period. The routine rituals are performed to ask for salvation to the Almighty so that all activities of the residents of Pedukunan Sonyo will be blessed and safe. How is the ritual performed so that both religious followers can be involved in it. This concept is more directed at how the ritual functions and how they perceive the ritual itself.

AritualaccordingtoVictorW.Turner(1967:19inAbdullah,2002)is “...prescribed formal behavior for occasions not given over to technological routine, having reference to beliefs in mysticalbeing or powers". It is done at a predetermined time and has a reference to something that has mystical powers. It is an expression of religious ceremonies that reflect the system of the human relations with the spiritual world. Meanwhile according to Helman (in Mudjahirn Thohir, 1999) essentially the ritual has three purposes: psychological, social, and protective. Having a psychological purpose means that any ritual organized is intended to acquire ways of expressing and receiving in the sense of unpleasant emotions. Having a social purpose because it is capable to reunite at least the 
public perception of the importance of the ritual performed. Similarly, the protective purpose of the ritual is that it is organized to protect those performing it from any kind of danger. Similarly, by performing rituals, anxiety, worry and other negative feelings can be reduced at least in terms of disease, death, and so forth.

For the performers, the ritual has a very important function. Through a ritual, an expression of obedience and submission can be found. For the residents of Pedukuhan Sonyo, and for other residents and communities, rituals are not just a blank expression. It is a medium to show the position of humans in the presence of the Almighty where humans are humble creatures. The ritual is also a medium to ask for salvation as well as expressing gratitude for everything that has been enjoyed and acquired. Similarly, through a ritual, humans acknowledge the existence of power that exists outside of themselves. By performing a carefully planned ritual, humans can negotiate with the spirit (some refer to it as the supra-natural being) so as not to interfere with their activities and life. A ritual serves as the space for human beings to communicate with the invisible, with fellow human beings, and with nature.

Both of the above concepts are used in order to see the dynamics of relationship of citizens Pedukuhan Sonyo. The concept of dialog is used to see the dynamics of the relationship and communication of the two groups in social practices and religious ritual. As for the concept of the ritual, it is used to view how far the ritual of Bersih Dusun forms the residents' perception about the role of the other group. Through the ritual, all elements and the residents involved are united in a common purpose. The ritual perceived here is not focused on the symbols performed by the community members, but on how it functions as a medium to build togetherness in the presence of differences.

In this paper, the author uses a structural functionalism perspective to analyze the problem. This perspective views society as functionally integrated into a form of equilibrium. This perspective is also known as the integration approach, equilibrium approach, or structural-functional approach. The structural functionalism perspective developed by Talcott Parsons has several basic assumptions, namely (1) the community should be seen as a system of parts which are interconnected with one another; (2) thus, the influence of the relationship between these parts is double and reciprocal; (3) even though social integration can never be perfect, it is fundamentally the social system that always tends to lean toward equilibrium which is dynamic; (4) even though dysfunction, tension, and deviation always take place, these conditions will naturally be resolved by itself through adaptation and institutional- 
ization processes, (5) changes in the social system in general is happening gradually, not revolutionary; (6) essentially, social changes arise from three kinds of possibilities: adjustment carried out by social system of adjustments coming from the outside; growth takes place through a differentiating and functional process; and new discoveries by members of the community; (7) the most important factor in the power of the social system integration is the consensus among members of the public about certain societal values.

\section{DIVERSITY MANAGEMENT STRATEGIES}

The community of Pedukuhan Sonyo is simple, still basing their life on subsistence patterns, they believe the nature has given them everything, for that they have always been friendly with nature, and are always trying to communicatewith it with avariety of expressions. Their harmony with natureis reinforced by the new religion that came to them not long ago, hopefully full of teachings of love (Islam and Buddhism). When morning comes, the routines keep recurring in the life of the Pedukuhan village. This is truly a beautiful stagnation for them, but of course will probably give the impression of being 'old-fashioned' for those who fond of modernization and globalization that are all fast-paced, stylish and new.

As a Pedukuhan that cannot be categorized as traditional, it will be important to tell how individuals in the community can maintain and strengthen each other in dealing with various issues of neighborly life, up to the more complex life in a village. When the 'invasion' of information through print and television media that illustrate the violent character of a particular religion because of different symbols, or news about the sectarian violence that occurred across the archipelago, between individuals, between groups, tribes, even between the races, but it does not affect the community of the Pedukuhan.

Admittedly, there are some issues in everyday life, between individuals, between families, even between groups also happened in this Pedukuhan, but it did not involve physical clash, and all could be resolved through a simple mechanism that is run and believed by the whole members of the community. The mechanism is simple because it is complicated and consists of a variety of rules, but every citizen strives to do what is called consensus, and in addition, the residents of the village also know the 5 basic foundations in the community (1) one shall not violate any applicable state law, (2) one shall not hurt fellow human beings (3) one shall not lie (4) one does not expect to have enemies and shall not necessarily try to find friends, and (5) one shall always look for true virtues. The five basic rules is the implementation, or perhaps part of the essence of Pancasila 
that becomes the basis of the Unitary State of the Republic of Indonesia today that seems increasingly not so strong anymore to be the philosophy of Indonesia.

Looking at the harmony of people's life at Pedukuhan Sonyo of course will raise the following question: what is the main factor that encourages those community members to be able to endure the hardship of their lives amid the hustle and clash of globalization that go hand in hand with the changing environment and the invasion of pop culture from many unexpected sources. In real life, society constantly changes and moves towards that in line with the more modernist community. In the past, every home had a joglo (a gathering place) which is usually separate from the main house. Now things have changed. We no longer see a joglo for guests but instead spaces inside the house are used for people to gather. They no longer sat on the floor cross legged but instead on modern chairs or sofas. It is in fact a big change.

Classes among the community also have gradually been created although it does not stratify people based on ownership of objects or wealth. Many of the youths at Pedukuhan Sonyo have higher level of education. Some even have a college degree and managed to work in government offices. The changes that occur in such a massive and sporadic manner of course require values and norms or at least a guideline in which the whole community will be able to maintain harmonization of relations between community members without discriminating each other by judging on the basis of status and identity of every individual in the community.

This is certainly not an easy thing to realize since identity is not singular in nature, but it is something that is constantly changing, adapting to time, place and circumstances (context); it is the fact that identity is composed of a set of relations, but it is equally important to affirm that identity can also be a single entity, something that is natural in a whole. Similarly the status of someone that is normally obtained through hard work or efforts, is also something important to appear, assert and maintain in the community.

The fact that strengthening identity will not (temporarily) replace the values that have been instilled so long by community members. The community of Pedukuhan Sonyo has applied the basic values in which they believe in the shared understanding of ways of life, and that the whole family of the community is the nuclear family without having to look at identity, religion, status, and gender of its members. Community members who see themselves as a nuclear family always have to take care and protect each other. Of course there will be a lot of problems that might occur, but all sorts of issues can be resolved through a family mechanism that has been passed down from 
older generations which is intertwined with the basic values of public life.

\section{BERSIH DUSUN RITUAL: CREATING A ROOM FOR COMMUNITY INTEGRATION}

Social relations that have been strongly established in Pedukunan Sonyo can never be separated from the involvement of all elements of the community itself. Althoughthevillageis situatedbehinda mountain, Pedukuhan Sonyo has demonstrated a potential for wisdom developed in abroader sphere.In the dynamics of their daily life, the residents of Sonyo are not stuck on the question of conflict based on differences of belief, especially in terms of the distribution of roles each group in the community plays. In any activity, with no exception to religious activities, the involvement of all the elements of the community is very visible. Both Buddhists and Muslims engage in one form of cooperation in order to facilitate the festivals.

On a three-yearly cycle, the residents of Pedukunan Sonyo hold a shared ritual participated by all members of the community. Every three years' period, there are two rituals in the village which are filled with a series of events. In fact, in the ritual, prayer is conducted together. Similarly, in the ritual that takes place in this hamlet, the main event is praying to the Almighty so that the residents are given salvation and blessed throughout their activities. In addition, the purpose of this ritual at the same time is to serve as an expression of gratitude for what they have achieved in previous years. The ritual is performed every Friday Kliwon (Javanese calendar) in the month of December. The Bersih Dusun ritual held on December 27, 2013 took place at the home of the hamlet head.

The ritual performed by the residents in this hamlet has a lot of unique features. Among the uniqueness in the series of ritual is the way the prayer is performed. As mentioned earlier that in Pedukuhan Sonyo there are two groups with different beliefs, and each would like to contribute to the hamlet. One of the forms of the contribution is praying to God for the safety of the residents in the days to come. In this ritual, both Buddhists and Muslims pray according to their own beliefs. It is a prayer event and is carried out in the same room, which is at home of the hamlet head where the event is centered.

Muslims pray with interspersed praises to Allah and blessings on Prophet Muhammad. In addition, tahlilan (recital of the oneness of Allah) is recited by adult males. Their clothes were distinctive; those often worn when doing activities of worship such as wearing skullcap, sarong, and Islamic prayer beads as well as other attributes. They solemnly pray, led 
by a religious leader (imam). The ritual of praying is performed at about 8 p.m. at night after Isha prayer time. The male adults sit with their mouth busy chanting a series of prayers of salvation.

Notfar from these Muslimmen, sat someadult males but were not included in the group reciting the prayer. They are Buddhists who also had the same purpose. They also joined the activity of performing a ritual prayer for the salvation and harmony of the Pedukuhan Sonyo residents. When the Muslims started praying, they did not leave the room. They took the position of sitting in the corner of the room because the same room will be used for prayer by them (the Buddhists). They pray in accordance with their own belief which also asked for salvation.

Theritualwasalsofilled withotheractivitiesheld bythevillageresidents especially activities related to entertainment. Jatilan and wayangan were two events organized between prayer events. Kelompok Jatilan (the Jatilan Entertainment Group) is a group that originates from Pedukuhan Sonyo and all the instruments are played by the local residents). Before the performance in each event, they always do a series of rehearsal. They have a routine practice each week. The owner of the musical instruments were also locals and happen to be a devout Buddhist. The practice is done at night to avoid interfering with their regular jobs during the day. The residents involved were composed of men and women. The voice artists also come from the hamlet. The Group's music is often played during events held both at Pedukuhan Sonyo, and outside the hamlet.

The Wayangan (Javanese puppet show) is also shown as part of the entertainment in a series of rituals in the hamlet of Pedukuhan Sonyo. The puppet shown is usually held night which takes place after the events of common prayer is completed. Sometimes, a puppeteer in a wayangan show comes from outside the hamlet, in addition to the available puppeteers. During the entertainment, there is no divider between Buddhists and Muslims. They share the joy of the entertainment together. In addition, the players are never segregated because of the difference of religion. They play musical instruments and perform together to entertain residents of the hamlet all night long.

The phenomenon of the rituals conducted in the hamlet as outlined above can at least demonstrate first, the effort to build mutual understanding among the residents, especially between the Buddhist and Islamic followers. Both Buddhists and Islamic adherents come together in a forum called a ritual. Rituals in other places usually do not involve groups outside of one's own. What happened at Pedukuhan Sonyo is a reflection of how the 
residents put forward a sense of humanity without being blinded by sentiment in which one often considers their own group to be the most correct.

Second, the ritual conducted in the hamlet is the medium for unification of different groups. This ritual is not claimed by a certain group with a certain belief, so as to allow the creation of a sense of shared responsibility in developing the hamlet for all people in the broad sense. Both the Muslims and Buddhists have a sense of belonging of the hamlet they live in. They (the two groups) do their best to contribute in accordance with their respective capacities without getting rejection from the other. Here, the ritual performed in the hamlet serves not only as a medium to ask for salvation to the Almighty, but also as the room that brings together both groups to reach the same goal with their own way. Tensions, however, at the very least can be minimized and even reduced so that it is no longer a belief difference as a factor that triggers conflict.

Third, through the Bersih Dusun ritual, recognition of other groups can be established. The involvement of both groups in the ritual has confirmed us that in the community (especially in rural areas) people still have very high appreciation of the existence of human beings or other groups. The existence of other groups in the context of Buddhist and Muslim relations in Pedukuhan Sonyo is not only found in theory, but it is also manifested in a variety of shared activities such as the involvement of each member of the groups in a ritual, including religious one. The Bersih Dusun ritual, however, is not based on religious groups, but rather it is based on a common vision about the importance of the ritual so that it becomes a collective activity of the residents in general. It is at this point that the brotherhood between the residents is becoming more powerful. The ritual requires each other's participation and gives each other a chance to do and contribute in various forms on every opportunity they can share together.

The above discussion of the harmonious relation between the Muslims and the Buddhists, if traced back, shows that Islam is actually very open and respects other people's existence. In the non-theological or social development area, Islam is so very accommodating to the existence of other groups, unlike the case with other areas, especially with regard to the theological aspects (aqida/creed). With regard to Islamic theology (creed), Islam draws a clear line of demarcation. In this matter, Islam appears to be very exclusive. This affirmation of Islamic creed is enshrined in the Qur an surah Al-Ikhlas and surah Al-Kafirun and reflected in the sahadah (two sentences of profession). This is the central doctrine of Islam 
called the tawhid, which is the profession of omnipotence and absolute God and assertion that Muhammad being the last Prophet sent by God to mankind on Earth.

The exclusive claim of Islam as reflected in the theological doctrines does not mean Muslims should become exclusive and deny pluralism. Because Islam also emphasizes inclusivism, as stated in Islamic primary sources (e.g. Q. S al-Kafirun: 6, Q.S.al-Hujarat: 13) and also as practiced in the early history of the formation of the Islamic community. Description of the ideal of harmony between Muslims and nonMuslims, as exemplified by the Prophet and which later became the model for the behavior of Islamic state and community life can be seen in the details of the "Charter of Medina". In the Charter, the rights of the followers of Judaism to coexist peacefully with Muslims are explicitly stated., with the Charter, the status of the Jewish people was lifted from tribal clients into the legitimate residents along with the Muslims. There is no difference in treatment between the two. Such a position was never owned by Jewish people since the invasion of Babylonia in $586 \mathrm{BC}$.

In the state of Medina, the Jews could observe the teachings of their religion in accordance with the teachings of the Torah. In addition, the State of Medina also guaranteed and assumed the responsibility related to the Jewish people. The Medina State provided such fair treatment without discrimination, in particular, against the Jewish community. It was during this period that the Jewish civilization with a variety of its aspects reached its "golden age» under the rule of Islam.

The condition was also enjoyed by the Nazarenes, especially during the post-"futuhat" Mecca. The Christians of Najran Yemen went to the Prophet to clarify their position vis-à-vis the Islamic State. Their delegation was well received by the Prophet. Some of them later converted to Islam. While the other remained on their religious beliefs within the framework of the Islamic State. The Prophet then solidified their position as the special ummah, a status enjoyed by the Jews.

The practice of harmony as exemplified by Prophet Muhammad was succeeded by the Companions of the Prophet, as did Omar bin Khattab when expanding into Byzantine Christian territories. When the region was conquered, Umar made an agreement with the local Bishop in which it was described that Islam would guarantee the existence of Christians in the reign of Islam under the principles of equality, justice and freedom granted by the rulers of Islam to these peoples, that later led the Christians to grow and develop. Even in the first century of the Hijrah, the majority of the population in the Muslim political 
entity were Christians, the condition which was not found in previous periods such as during the Christian reign of Byzantine, Rome, or Greece.

The noble principles of the unity can also be found in most areas of Muslim rule, such as in the subcontinent of India. The region's adherents, the Hindus and Buddhists have the same rights as the Jews and Christians. When Islamic rule came to an end, the followers of other religions remain in their original belief. This proves that the principles of tolerance or harmony remain the grip for the Muslim rulers.

Even the development of Islamic civilization which reached its peak during the Abbasiya (Caliphate), among others, was caused by the development of the theology of this harmony. It would be inconceivable to imagine the advances of science and civilization of Islam without participation from other religious adherents. In this stage of the development of Islamic culture with all its aspects almost always rests on a root of unity. The development of science and technology at the time of the Abbasiya that gave birth to various branches of science began with the involvement of experts from non-Islamic society starting with the massive translation process as from the Nazarenes and the Persians.

In the smallest scope, the brotherhood established shows how the practice of tolerance and respect for differences take place in Pedukuhan Sonyo. The ritual is just one of the events in which the practice of tolerance by the residents can be found. The ritual serves as a room or medium capable of uniting various differences. The differences in both the habits and beliefs of the groups (Islamic and Buddhist) are reduced and even united by the ritual. All people have a common perception regarding the essence of the ritual conducted without looking at the origins and identity inherent in each group. What takes place at each performance of ritual in Sonyo provides some clues about how interest groups are able to accommodate aspiration to minimize the potential conflict. The differences that are often seen as a source of tension have thus become a new strength to create harmony. Departing from the ritual, social integration of the community in Sonyo remains strong. Social integration in society can be achieved when elements in it have the opportunity to interact socially. In addition, social norms and customs are also among other important factors in achieving social integration. This is due to the fact that social norms and customs that govern the behavior of the community members by upholding the imperative about how people should behave. Nevertheless, the achievement of social integration in society requires sacrifice, in terms of both immaterial and material 
sacrifice. The basis of sacrifice is the adjustment between the difference of feelings, desire, the size and the assessment in the community. Therefore, social norms of reference to act and behave in society will provide the guidelines for a way to socialize within the community.

Portrait of unity backed by growing social integration can also be seen in the relations between Muslims and other groups in several other places. In South Sulawesi, for example, while the Bugis-Makassar community is often identified with Islam, in terms of social contact, they are very open to other groups. This happens in Makassar Sidenreng Rappang where there is encounter between Islam and the Towani Tolotang (Hinduism). Both groups live and unite in a settlement.

The Towani Tolotang settlement which is situated next to the other community groups has enabled mobility and social relations between the two communities. The pattern of the relationship between Towani Tolotang and the Muslims in the vicinity is not only limited to neighborhood matters, but it could also take the feeling of kinship. At the neighborly level, the relationship is based on intensity of the encounter can happen at any time because the groups coexist. Helping each other in some daily activities serves as one of the main factors that strengthens their relationship. When the help each other, they no longer display concerns about different conviction they believe in but sense of brotherhood based on the neighborly relationship is more important to them.

Settlement patterns of the Towani Tolotang and the Muslims that happens to be side by side has allowed intensive communication to occur. The frequency of their encounter also occurs intensely. At Amparita, the homes belonging to the Towani Tolotang or the Muslims other do not have a significant difference. The architectural construction and is the same, which is a typical house of the Bugis. The distance between one house and the other is not far away, usually only separated by a fence and the yard which is approximately 5 meters. The Towani Tolotang, despite living in the same hamlet, are not exclusive. In between their houses, there is also the home of the Muslims.

The condition at Pedukuhan Sonyo is also not far different. People of both religions mingle and communicate well. On other issues, such as appreciating and respecting each other (recognition of other groups) are also carried out by residents with the exchange of foodstuffs such as during lebaran (Islamic holy day) can be seen during both Eid al-Fitr and Eid alAdha. After celebrating the Eid al-Fitr, Muslim residents for example, hand out alms (zakat) collected. The alms are distributed to those entitled to receive them. 
One interesting phenomenon that occurred among the Muslim residents at the time of zakat distribution (where there was plenty of rice left) was that it was distributed to the Buddhists. It also occurred after the feast of Eid alAdha. When the distribution of sacrificial meat took place, the Buddhists also received coupons just like the Muslims. According to Suparno (39), the gift coupons were intended for anyone to pick up the meat in person. Suparno reported that up to now, they have always come take sacrificial meat provided by the committee.

The above view shows that at least in practice, socio-religious life of the people has a very intensive and dynamic relationship. Segregation does not occur in particular concerning religion among them. Both religious groups under certain conditions are very exclusive but in other conditions they are very open to the existence of other groups. It does have a direct impact on the already established communication that occurs where various activities demonstrate the success of positioning one group in the presence of another so that conflict can be avoided.

The solidity shown and group solidarity built are getting stronger because it is based on the mutual understanding and commonality of vision related to the needs or position of the groups respectively. They managed to sort and select appropriate actions done without denying the existence and each other's role. Ritual and other social activities do not scramble the role, but instead serve as adhesive and reduction of tension among residents. In the end, the existence of different groups thus increasingly provides opportunities for the harmonization of life among the people because it is based on the principle of openness and respect for others.

\section{COCLUSION}

The relations between Buddhists and Muslims in Pedukuhan Sonyo show how communities in a small Hamlet build solidarity that goes beyond religion. What this study demonstrates is how different groups of people manage diversity that is built on the difference itself and gives birth to cohesion between them. The difference, as can clearly be seen in many places, thus often became justification to blame the other. The case in this study shows the opposite, both groups live together in harmonious situations that even penetrate the boundaries of belief.

At this level, the diversity is no longer a question of beliefs that are considered urgent among groups. With similar culture, different groups have been able to show understanding of sublime cultural values which are relatively the same. Here, they no longer stress on the polarization of non-Muslims and 
Muslims, but the similarity of the Javanese culture. It confirms that the commonality of culture that eventually gives birth to a bond that is important in establishing a good relation among members of different groups. Here, social capital serves as a reinforcement of social solidarity. Solidarity is formed because people do things together, not because the individuals are of the same value or belief.

This research confirms that solidarity demonstrated by the community of Pedukuhan Sonyo is a portrait of a community that is successful in overcoming group's selfishness and ego. There are three important things responsible for managing diversity based on the findings of this research. First, diversity is not always a trigger for conflict, on the other hand, it should serve as the adhesive to form a society despite different beliefs. In spite of difference in belief, it turns out that intensive and balanced communication without involving the interests was able to reduce the tension in the middle of the community. The difference of belief is just one of the many differences which, if managed well, will deliver a secure and peaceful condition. This kind of paradigm shift is also found in the middle of the community of Pedukuhan Sonyo, both Buddhists and Muslims have to continue to develop themselves without bothering the other's existence.

Second, in a society there is a lot of potential that can be developed in order to create harmony. The Bersih Dusun ritual still practiced and preserved to this day turned out to be an important contribution to the good community relations and communication in the hamlet of Pedukuhan Sonyo. The ritual not only concerns how to build a good relation with God, but also creates harmony with our fellow human beings that exceeds the interests of each individual. The ritual not only builds connection between humans and God, but also becomes a tool to bond people far beyond the differences of religion. In this condition, the ritual has been able to show a function that works to reduce potential for tension.

Third, the involvement of all elements of society is important to be continuously encouraged in order to provide a space that is capable of accommodating all interests. The involvement and engagement of all parties without labeling provide wider room for different groups to take part in any collective activity not only enjoyed by members of a particular group, but also by members of the other. The distribution of function to all elements in society will have an impact on trust in the presence of other groups. Integration will later appear in the spirit of respect for the existence of others. Both the Buddhists and Muslims lived side by side, and are not clustered based on their conviction, in particular with regard to settlement, so they continue 
to integrate and mutually need each other.

In the future, it is crucial to always accommodate a wide range of community discernment as an attempt to minimize the hostility that often triggers conflict. What is indicated by the community in a remote hamlet in Yogyakarka can serve as an example of how to manage diversity and brought to a much wider area. The Pedukuhan Sonyo community has exemplified a good lesson on how collective solidarity can be built on differences without denying the existence of other groups (minorities). They have been able to allocate their respective roles so as to avoid conflict which interferes with the harmonious relationship they worked hard to establish. This, in fact, reflects that they have succeeded in managing difference and diversity into a strength although it is only practiced within the small scope of the dynamics of Indonesian government.

As a pluralist nation, it must be noted that we should never split just because of the difference of beliefs. The difference should become a precondition for the formation of an open society. The spirit of appreciation can at least spread to penetrate all aspects of life. The existence of other groups outside one's own will add dynamics to the relationship that tends to move toward an increasingly complex pattern. What is indicated by the community of Pedukuhan Sonyo is that social life is full of meaning. Their steadfastness regarding the implementation of the ritual is not only limited to the normative-practical level, but it also arrives at substantive-applicative by continuing to cultivate the sense of togetherness by acknowledging differences exist among them. This is the true spirit of democracy, where differences are managed and used as a force to establish unity and a sense of togetherness.

\section{REFERENCES}

Abdullah, Irwan. 2002. Simbol, Makna dan Pandangan Hidup Jawa: Analisis Gunungan pada Upacara Grebeg. Yogyakarta: Balai Kajian Sejarah dan Nilai Tradisional Yogyakarta.

Ali, As’ad Said. 2009. Negara Pencasila: Jalan Kemaslahatan Berbangsa. Jakarta: LP3ES.

Azra, Asyumardi. 2003. "Merajut Kerukunan Hidup Beragama antara Cita dan Fakta, dalam Jurnal Harmoni: Jurnal Multikultural dan Multireligius, Vol II No. 7, Juli-September. Jakarta: Puslitbang Kehidupan Beragama, Badan Litbang Agama dan Diklat Keagamaan Departemen Agama RI.

Baidhawi, Zakiyuddin. 2006. Kredo Kebebasan Beragama. Jakarta: PSAP. Daya, Burhanuddin. 2004. Agama Dialogis: Merenda Dialektika Idealitas dan 
Realita Hubungan Antaragama. Yogyakarta: Mataram-Minang Lintas Budaya.

Hasse J. 2012. "Keberadaan Towani Tolotang di Kabupaten Sidenreng Rappang Sulawesi Selatan: Studi tentang Konstruksi Negara terhadap Agama di Indonesia", Disertasi. Yogyakarta: Agama dan Lintas Budaya, Sekolah Pascasarjana UGM.

Ismail, Arifuddin. 2012. Agama Nelayan: Pergumulan Islam dengan Budaya Lokal. Yogyakarta: Pustaka Pelajar.

Knitter, Paul F. 2004. Introducing Theologies of Religions. Maryknoll, New York: Orbis Books.

Kompas, 29 Mei 2013.

Kung, Hans. 1991. Global Responsibility in Search of a New World Ethic. New York: Crossroad.

Misrawi, Zuhairi. 2007. Al Quran Kitab Toleransi. Jakarta: Fitrah.

Nasikun. 2006. Sistem Sosial Indonesia. Jakarta: Rajawali Press.

Nasr, Seyyed Hossein1968. Science and civilization in Islam. Massachusetts: Harvard University Press.

Qodir, Zuly. 2012. Sosiologi Politik Islam: Konstestasi Islam Politik dan Demokrasi di Indonesia. Yogyakarta: Pustaka Pelajar.

Thohir, Mudjahirin. 1999. Wacana Masyarakat dan Kebudayaan Jawa Pesisir. Semarang: Bendera.

Turner, Victor W. 1967. "Symbols in Ndembu Ritual”, in Victor W. Tuner, The Forest of Symbols: Aspect of Ndembu Ritual. Ithaca: Cornell University Press. 